日消外会誌 $19(1): 1 \sim 11,1986$ 年

原

胃癌に対する噴門側胃切除術の適応

\author{
都立駒込病院外科 \\ 鈴木 力 粟根 康行 北村 正次 \\ 小西 敏郎 荒井 邦佳 神前 五郎

\section{INDICATION OF PROXIMAL GASTRECTOMY FOR GASTRIC CANCER} \\ Tsutomu SUZUKI, Yasuyuki AWANE, Masatsugu KITAMURA, \\ Toshiro KONISHI, Kuniyoshi ARAI and Goro KOSAKI \\ Department of Surgery, Tokyo Metropolitan Komagome Hospital
}

\begin{abstract}
上部胃癌に対する胃全剔術施行例124例の臨床病理学的検索から, 噴門側胃切除術 (噴切)では郭清 に最も制約を受けると考学られるNo. 4d, 5, 6に転移をみとめる危険性（相対的リンパ節転移危険性） は No. 10, No. 11 と同等以上であり，特に $\mathrm{n}_{1}(+)$ 例や ps（十）例では転移をきたしやすい部位である との結論を得た.

当科では噴切は上部胃癌根治手術としては，幽門側胃を温存し，No.10, No. 4d, No. 5, No.6を郭 清しない $\mathrm{R}_{1}$ 郭清で十分な根治性の得られる症例にのみ商応となる, 一つの縮少手術術式であり, 局在 $\mathrm{C}(\mathrm{E})$ の, 肉眼的に Stage I の表在癌と判断され, 組織学的にも $\mathrm{m}, \mathrm{sm},(\mathrm{pm})$ 癌で $\mathrm{n}(-)$ と予測 される早期の症例のみに適応となる術式と考穴ている.
\end{abstract}

柬引用語 : 上部胃癌, 噴門側胃切除術, 上部胃癌の臨床病理学, 胃癌の縮少手術

\section{はじめに}

噴門側胃切除術（以下噴切）は上部胃癌に対する根 治手術として，胃全剔術（以下全剔）とともに多くの 施設で施行されている術式である。噴切を行うことの 意義は，幽門側胃を温存することで術後の生体機能に 対し，いろいろ有利な点がある ${ }^{1)}$ と期待されるからで あるが，反面本術式の根治性は全剔と比較した場合， 胃切除範囲，大弯右，幽門上・下などのリンバ節郭清 が制限されるため, ある程度劣ることは否定しえない。 そのため噴切を行うについては常にこのことを考虑に 入れ，噴切で十分な根治性が得られると考えられる症 例を選択する必要がある。

当科では従来より比較的早期の上部胃癌症例に対し て積極的に噴切を行ってきており，その成績の一部は すでに発表している21.

今回は上部胃癌の進展に招ける臨床病理学的な特徵 を検索するとともに, 当科噴切施行例の手術成績につ

$<1985$ 年 9 月 11 日受理 >別刷請求先：鈴木 力 干951 新潟市旭町通 1 新潟大学医学部第 1 外科
いても検討を行い,それらの結果に基づき部胃癌根 治手術としての噴切の意義，適応基準などについて考 察を加えた。

なお本稿で論ずる上部胃癌とは, 局在 Cを中心とし た胃癌であり，C， CM, CE, CME 癌を意味している。

I. 上部胃癌の臨床病理学的検討ーリンパ 節転移と浆膜浸潤を中心として

噴切の適応を考える上で, 上部胃癌の進展状況につ いての臨床病理学的な特徽を把握して拈くことは重要 である、そこで，いろいろの観点から上部胃癌におけ る所属リンバ節への転移，およびリンバ節転移と癌腫 の壁澡達度, とくに椋膜漫潤の有無との関係を中心と して分析し，検討を加亲た。

1. 対象拉よび検討方法

対象は昭和 50 年 4 月より昭和 58 年12月までに当科で 切除した上部胃癌症例の うち， $\mathrm{R}_{1}$ 以上のリンバ節郭清 を行った全剔例で,十分な組織学的検索のなされた124 例である。これらの症例のうち101例は荤尾側・脾, 23 例は脾の合併切除を伴っている。

リンパ節転移に関する検討は, 局在 C 胃癌における 
1 群㧄よび 2 群リンパ節を検索対象とし， 1 群リンパ 節はNo. 1, 3を小弯側リンパ節, No. 2, $4 \mathrm{~s}$ を大弯側り

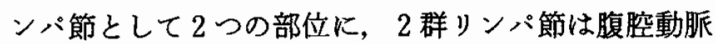
幹周囲の No.7, 8, 9 ; No. 10 ; No.11および大弯右, 幽門上・下の No. 4d, 5,6の 4 部位に分け, 全体として

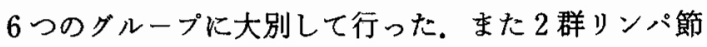
に関しては，当科における噴切の標準的リンパ節郭清 （後述）に際して, 郭清が完全と考兄られるNo.7,8,9 と, 不完全または郭清の対象から除かれる, No. 10,

No. 11，No.4d, 5,6とに分けての検討子試みた。なお 癌腫が食道へ浸潤した場合などには下部食道, 綻隔内 リンパ節も問題となるが，これらについての詳細は別 にゆずり ${ }^{3)}$, 本稿では腹空内リンパ節を中心として検 索を行った。

浆膜浸潤については，胃癌取扱い規約・改訂第 9 版 ${ }^{4}$, 第10版 ${ }^{5}$ 飞従い, 癌腫の壁深達度から対象例を ps (十)群とps（一）群に分忛, リンパ節転移との関連性 を検討した。

評価対象例数は, No.1, 3, No. 2, 4s, No. 7, 8, 9, No. 10は検討対象124例全例, No.11は膵尾側合併切除 例および䐙温存例でも十分なNo. 11郭清が行われた と判断された117例で, No. 4d, 5, 6については胃癌取 扱い規約・改訂第 10 版 ${ }^{5}$ に従って, No.4リンパ節をNo. $4 \mathrm{~s}$ と No. $4 \mathrm{~d}$ に分類して検索を行った119例である.

統計学的な処理は $x^{2}$-testにて行い, 対象例が少数 の場合には YATES の補正, Fisher の直接確率計算法
により修正を加えた。

\section{2. 結果}

1）上部胃癌のリンパ節転移と部位別リンパ節転移

(率) (表 1)

i . 上部胃癌のリンパ節転移 (率)：対象124例中, $\mathrm{n}(-)$ 例は21例（16.9\%）にすざず，103例（83.1\%）

表 1 上部胃癌のリンパ節転移と部位別リンパ節転移 (率)

\begin{tabular}{|c|c|}
\hline$n(-)$ & $21 / 124(16.9)$ \\
\hline$n_{1}$ & $27 / 124(21.8)$ \\
\hline $\mathrm{n}_{2}$ & $60 / 124(48.4)$ \\
\hline $\mathrm{n}_{3,4}$ & $16 / 124(12.9)$ \\
\hline \multicolumn{2}{|c|}{ 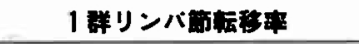 } \\
\hline $\begin{array}{l}\text { 小弯唃リンバ箅 } \\
\text { No. } 1.3\end{array}$ & $88 / 124(71.0)$ \\
\hline 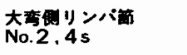 & $57 / 124(46.0)$ \\
\hline 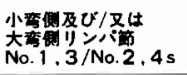 & $95 / 124(76.6)$ \\
\hline \multicolumn{2}{|c|}{ 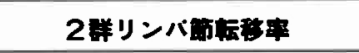 } \\
\hline No. 7.8 .9 & $53 / 124(42.7)$ \\
\hline No.10 & $18 / 124(14.5)$ \\
\hline No.11 & $44 / 117(37.6)$ \\
\hline No. $4 \mathrm{~d} .5 .6$ & $32 / 119(26.9)$ \\
\hline
\end{tabular}

表 2 リンパ節転移の相関関俰

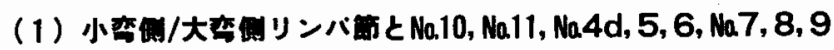

\begin{tabular}{|c|c|c|c|c|c|c|c|c|c|}
\hline & & \multicolumn{2}{|c|}{ No.10 (t) } & \multicolumn{2}{|c|}{ No.11 (+) } & \multicolumn{2}{|c|}{ No. $4 d, 5,6(t)$} & \multicolumn{2}{|c|}{ No. $7,8,9$} \\
\hline 小咢僠リンパ范 & $(+)$ & $16 / 88$ & $(18.2) 7$ & $39 / 83$ & $(47.0)_{7}$ & & & & \\
\hline No. 1,3 & $(-)$ & $2 / 36$ & $(5.6)]^{\top}$ & $5 / 34$ & $(14.7)^{]^{*}}$ & & & & \\
\hline 大新側リンバ筑 & $(+)$ & $13 / 57$ & $(22.8) 7$ & $32 / 56$ & $(57.1) 7$ & & & & \\
\hline No. $2,4 \mathrm{~s}$ & $(-)$ & $5 / 67$ & $(7.5)-$ & $12 / 61$ & $(19.7)^{] *}$ & & & & \\
\hline 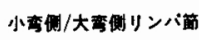 & $(+)$ & $17 / 95$ & $(17.9) 7$ & $41 / 90$ & $(45.6)_{7}$ & $30 / 90$ & $(33.3) 7$ & $48 / 95$ & $(50.5)_{7}$ \\
\hline No. $1,3 /$ No. $2,4 \mathrm{~s}$ & $(-)$ & $1 / 29$ & $(3.4)]^{*}$ & $3 / 27$ & $(11.1)^{3 *}$ & $2 / 29$ & $(6.9)$ & $5 / 29$ & $(17.2)]^{* 2}$ \\
\hline 部 & & $18 / 124$ & $(14.5)$ & $44 / 117$ & $7(37.6)$ & $32 / 119$ & $9(26.9)$ & $53 / 124$ & $4(42.7)$ \\
\hline
\end{tabular}

(2) No.7, 8, 9 と No.10, No.11, Na.4d, 5, 6

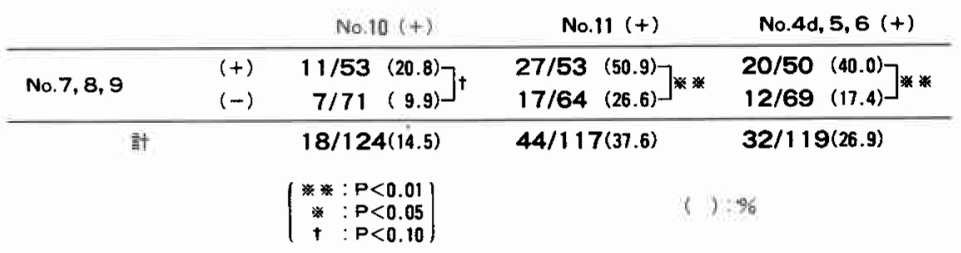


と, 大多数の症例は $\mathrm{n}(+)$ 例で, しかむ $\mathrm{n}_{2}$ 以上の進 行例が $61.3 \%$ 占めていた。

ii. 1 群リンパ節転移率：1群リンパ節転移率は, No. 1, 3 71.0\%, No.2,4s 46.0\%であった. これら小 弯側, 大弯側のいずれかにでる転移 (+) の 1 群リン 八節転移陽性例は95例，転移率は76.6\% と非常に高率 であった。

iii. 2 群リンパ節転移率： 2 群リンパ節では, No. 7, 8, 9 42.7\%, No. 10 14.5\%, No. 11 37.6\%, No. 4d, 5, $626.9 \%$ と, No. 7, 8, 9, No. 11が40\%前後の高 い転移率を示し，次いでNo.4d, 5, 6, No.10の頻度で 転移を認めた。

2）リンパ節転移の相関関保（表 2)

i . No. 1, 3/No. 2, 4s 転移と No. 10, No. 11, No. $4 d, 5,6, N o .7,8,9$ 転移との相関関係：No. 1, 3に転移 （+）例は，（一)例に比較して, No.10転移が増加する 傾向にあり，No.11転移率は有意に高率であった。 た, No. 2, 4s 転移陽性例は陰性例より No. 10, No. 11 転移率が有意に高く，さらにいずれかの 1 群リンパ節 に転移をみた $\mathrm{n}_{1}(+)$ 例でも，これらリンパ節の転移 率は $\mathrm{n}_{1}($ (一) 例に比較して有意に高率であった。 No.4 d, 5, 6, No.7, 8,9 亿ついても， 1 群リンパ節転移陽性 例は陰性例に比較して，有意に高い転移率であった。 ii. 2 群リンパ節間の転移の相関関係一No. 7, 8, 9 と No. 10, No.11, No. 4d, 5, 6:2 群リンパ節の中で も高率に転移のみられた No. 7, 8, 9 亿転移 $(+)$ の症 例は，（一)例に比較して，No.10転移が増加する傾向 にあり，No.11，No.4d, 5, 6転移は有意に増加した。

3）ps とリンパ節転移の相関関係（表 3)

i。ps とリンパ節転移：対象124例についてみる と, ps (一) 例で $\mathrm{n}(-)$ 症例が多い傾向を示した. 2 群リンパ節まで転移陽性の $\mathrm{n}_{2}$ 症例は ps $(+)$ 例で有意 に頻度が高いが, $\mathrm{n}_{1}$ 症例, $\mathrm{n}_{3,4}$ 症例については有意差を 認めていない. ps (一) 例を ss 群と pm, sm, m 群に 分けて検討した場合, $\mathrm{n}(-), \mathrm{n}_{1}$ 症例は $\mathrm{pm}, \mathrm{sm}, \mathrm{m}$ 群 に多く, $\mathrm{n}_{2}, \mathrm{n}_{3}, 4$ 症例は ss 群に多いようであるが， いずれす有意差は認められなかった。

ii. ps とリンパ節転移の相関関係 : ps $(+), \mathrm{ps}(-)$ にかかわらず No. 1, 3, No. 2, 4s には高頻度に転移が 認められたが, ps (十) 例でこれら 1 群リンパ節転移 率が有意に高率であった。 2 群リンパ節転移は, ps(+) 例の方が No. 7, 8, 9で高頻度になる傾向がみられ, No. 10, No. 11, No. 4d, 5, 6では有意に高率となった. ps （一）例を ss 群と pm 以下の群に分けて検討すると，有 意差は認められないものの，全体に後者が低い転移率 であり，また, No. 10, No.11, No. 4d, 5,6への転移

表 3 Ps とリンパ節転移の相関関係

\section{（1）Psとリンパ简転移}

\begin{tabular}{|c|c|c|c|c|}
\hline & $\mathbf{n} \rightarrow$ & $n_{1}$ & $n_{2}$ & $\mathrm{n} 3.4$ \\
\hline Ps $(+)$ & 10/81(12.3) & $15 / 81(18.5)$ & $45 / 81(55.6) 7$ & $11 / 81(13.6)$ \\
\hline$P_{s}(-)$ & $11 / 43(25.6)]^{\dagger}$ & $12 / 43(27.9)$ & $15 / 43(34.9)]^{*}$ & $5 / 43(11.6)$ \\
\hline$\{s s \alpha, \beta$ & $7 / 35(20.0)$ & $9 / 35(25.7)$ & $14 / 35(40.0)$ & $5 / 35(14.3)$ \\
\hline pm,sm,m & $4 / 8(50.0)$ & $3 / 8(37.5)$ & $1 / 8(12.5)$ & $0 / 8(0)$ \\
\hline 壾 & (16.9) & $27 / 124(21.8)$ & $60 / 124(48.4)$ & $16 / 124(12.9)$ \\
\hline
\end{tabular}

(2) Ps と No. 1, 3/2, 4s, №. 7, 8, 9, №.10, No.11, №.4d, 5, 6

\begin{tabular}{|c|c|c|c|c|c|}
\hline & No.1,3/2,4s(t) & No.7, $8,9(+)$ & No.10(t) & No.111+1 & No.4d, $5,6(+)$ \\
\hline $\begin{array}{l}P_{s}(+) \\
P_{s}(-)\end{array}$ & $\left.\begin{array}{l}69 / 81(85.2) \\
26 / 43(60.5)\end{array}\right] \%$. & $\left.\begin{array}{l}39 / 81(48.1) \\
14 / 43(32.6)\end{array}\right]+$ & $\left.\begin{array}{l}16 / 81(19.8) \\
2 / 43(4.7)\end{array}\right]$ & $\left.\begin{array}{l}37 / 79(46.8) \\
7 / 38(18.4)\end{array}\right] *$ & $\left.\begin{array}{l}27 / 76(35.5) \\
5 / 43(11.6)\end{array}\right] \approx$ \\
\hline $\int \operatorname{ss} \alpha, \beta$ & $22 / 35(62.9)$ & $13 / 35(37.1)$ & $2 / 35(5.7)$ & $7 / 30(23.3)$ & $5 / 35(14.3)$ \\
\hline pm,sm,m & $4 / 8(50.0)$ & $1 / 8(12.5)$ & $0 / 8(0)$ & $0 / 8(0)$ & $0 / 8(0)$ \\
\hline \multirow[t]{2}{*}{ 鼓 } & $95 / 124(76.6)$ & $53 / 124(42.7)$ & $18 / 124(14.5)$ & $44 / 117(37.6)$ & $32 / 119(26.9)$ \\
\hline & & {$\left[\begin{array}{l}* \%: \\
*: \\
+\quad:\end{array}\right.$} & $\left.\begin{array}{l}P<0.01 \\
P<0.05 \\
P<0.10\end{array}\right)$ & $(1): \%$ & \\
\hline
\end{tabular}


陽性例はss 群のみにみられた。

4）上部胃癌に怙ける部位別リンパ節転移率からみ た相対的リンパ節転移危険性の比較（表 4)

各部位別のリンパ節転移率を統計学的に比較し, ぞ の部位のリンパ節により転移しやすいか，すなわち各 部位のリンパ節間の相対的な転移の危険性一相対的リ ンパ節転移危険性（以下，転移危険性）といら概念を 想定し，その大，小について考察を加えた。な掠 No. 1， 3 , No. $2,4 \mathrm{~s}$ は 1 群リンパ節として一括して比較, 検討 した.

i 、上部胃癌症例のリンパ節転移率と転移危険性： 1 群リンパ節は, 4 部位の 2 群リンパ節すべてに対し,
有意に高い転移危険性を示した。 No. 7, 8,9の転移危険 性はNo.11と差をみなかったが，No. 10, No. 4d, 5, 6 に対しては有意に高いといら結果であった。No.10は No. 11，No.4d, 5, 6より有意に転移危険性が低く，ま た No.11と No. 4d, 5,6では, No.11に転移危険性が高 い傾向がみられた。

ii . 1 群リンパ節転移陽性例の 2 群リンパ節転移危 険性の比較：1群リンパ節転移陽性例における No. 7, 8, 9の転移危険性は No.11と差を認めなかったが, No. 10,No. 4d, 5,6に比較して有意に高いということがい える. No.11と No. 4d, 5, 6の転移危険性はNo. 10 より 有意に高いが,これら 2 者の比較では, No.11の転移危

表 4 上部胃癌に扎ける部位別リンパ節転移率からみた相対的リンパ節転移危険性の 比較

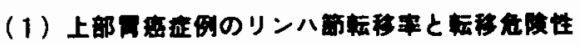

\begin{tabular}{|c|c|c|c|c|c|c|}
\hline & No. $1,3 / 2,4 \mathrm{~s}$ & \multicolumn{2}{|c|}{ No.7.8.9 } & No. 10 & No.11 & No. $4 d, 5.6$ \\
\hline 転移率( \%) & $95 / 124(76.6)$ & $53 / 12$ & $24(42.7)$ & $18 / 124(14.5)$ & $44 / 117(37.6)$ & $32 / 119(26.9)$ \\
\hline \multicolumn{7}{|c|}{ リンパ酶転移危険性 } \\
\hline \multirow[t]{4}{*}{ No. 1.3/2 } & $.4 \mathrm{~s}:>N_{0} 7.8 .9$ (P & $<0.001)$ & No.7.8.9: & $(P<0.001)$ & No.10:<Noll & $(P<0.001)$ \\
\hline & $>N_{0} 10$ & $<0.001)$ & & $>$ No.4d.5.6(P<0.01) & $<\mathrm{No}_{0} 4 \mathrm{~d}$ & $.6(P<0.05)$ \\
\hline & $>\mathrm{Na}_{11}$ & $<0.001)$ & & & & \\
\hline & $>\mathrm{No}_{0} 4 \mathrm{~d}, 5.6 \mathrm{f} \mathrm{P}$ & $<0.001\}$ & No.7.8.9 & No11：有意差なし & $N_{0} 11 \sim N_{0} 4 \mathrm{~d}, 5.6$ & $: P<0.10$ \\
\hline
\end{tabular}

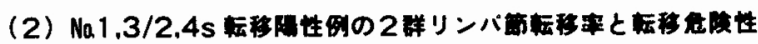

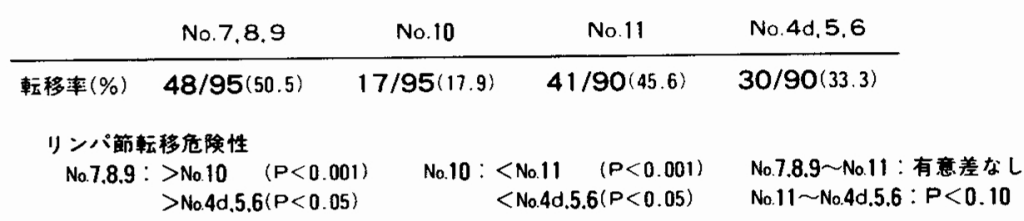

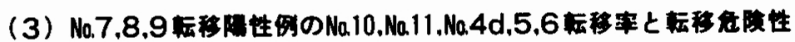

\begin{tabular}{|c|c|c|c|}
\hline & No. 10 & No. 11 & No.4d. 5.6 \\
\hline 転移事 $(\%)$ & $11 / 53(20.8)$ & $27 / 53(50.9)$ & $20 / 50(40.0)$ \\
\hline \multicolumn{4}{|c|}{ リンパ節転移危険性 } \\
\hline \multicolumn{2}{|c|}{$\begin{array}{rlr}\text { No.10: } & <\text { No.11 } \quad(P<0.01) \\
& <\text { No.4d.5.6(P<0.05) }\end{array}$} & \multicolumn{2}{|c|}{ No.11〜No.4d.5.6：有意差なし } \\
\hline
\end{tabular}

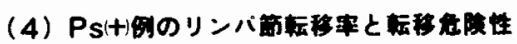

\begin{tabular}{|c|c|c|c|c|c|c|}
\hline & No.1, 3/2.4s & \multicolumn{2}{|c|}{ No. $7.8,9$} & No. 10 & No.11 & No. $4 d, 5.6$ \\
\hline 転移率 $(\%)$ & $69 / 81(85.2)$ & \multicolumn{2}{|c|}{$39 / 81(48.1)$} & $16 / 81(19.8)$ & $37 / 79(46.8)$ & $27 / 76(35.5)$ \\
\hline \multicolumn{7}{|c|}{ リンパ箅転移危除性 } \\
\hline \multirow[t]{4}{*}{ No. $1,3 / 2$} & $4 \mathrm{~s}:>\mathrm{N}_{0} .7 .8 .9$ & $\langle P<0.001)$ & No.10: & $<\mathrm{No}_{0.7 .8 .9}(\mathrm{P}<0.001)$ & No.7.8.9 No. 11 & \\
\hline & $>$ No 10 & $(P<0.001)$ & & $<$ No.11 $\quad(P<0.001)$ & No.7.8.9 No.4d.5.6 & ᄂ \\
\hline & $>$ No.11 & $(P<0.001)$ & & $<$ No.4d,5.6(P<0.05) & No. $11 \sim N_{0} .4 d .5 .6$ & \\
\hline & $>N_{0} .4 d, 5,6$ & $(P<0.001)$ & & & & \\
\hline
\end{tabular}


険性が高い傾向がみられた。

iii. No. 7,8,9転移陽性例の No. 10, No. 11, No. 4 d, 5, 6転移危険性の比較 : No. 7, 8, 9転移陽性例では, 他の 3 部位の 2 群リンパ節の5ち, No. 10が最も転移 危険性が低く, No. 11，No.4d，5，6に対して有意差が 認められた. No.11とNo.4d, 5,6の間には差がみられ なかった.

iv. ps（+）例における各部位のリンパ節転移危険 性の比較：1群リンパ節の転移危険性は 2 群リンパ節 すべてに対して有意に高い. No. 7,8,9, No. 11, No. $4 \mathrm{~d}, 5,6$ 転移危険性は相互に有意差を認めなかった が，No.10に対しては，いずれる有意に高かった。

5）癌腫の局在とリンパ節転移

癌腫の局在を主要な病巣の拡がりをるつ部位によ り, 小弯, 大弯, 前壁, 後壁, 全周性の 5 群に分け, これまで述べた種々の観点から検討を加えたが, 症例 が分散し，各群の症例数が少なくなることもあり，い ずれる有意差を認めなかった。ただし, 癌腫が全周性 の場合, 他の群に比較してPs (+) 例やリンパ節転移 率が高くなる傾向がうかがえた。

以上の臨床病理学的検索から, 上部胃癌症例のリン パ節転移が高率なこと, 各所属リンパ節間の転移にお。 ける関連性の強いこと, 癌腫の壁深達度が進むととも にリンパ節転移る増加することが明らかになった。 た, 転移危険性は 1 群リンパ節が最も高く， 2 群リン バ節では, 今回の分析結果を総合的に判断すると, No. $7,8,9 \fallingdotseq$ No. $11 \geqq$ No. $4 \mathrm{~d}, 5,6>$ No. 10の順位になる のと考えられた。

\section{II. 当科における喷切施行例の検討}

上部胃癌の臨床病理学的検索とともに, 当科での噴
切施行例についても検討を加えた。

1. 対象症例および検討方法

昭和 50 年 4 月より昭和 58 年 12 月までの期間に当科で 噴切を施行した症例は39例である。これら症例のらち, 時代により一部変遷はみられる2すのの, 次に述べる 当科での適沁基準, 基本術式の原則に従い, 上部胃癌 に対する根治手術として噴切を施行した34例を対象と し，その手術成績を中心として検討を加えた. 対象34 例は組織学的には全例腺癌であった。 ほかに腹部食道 癌や平滑筋肉腫などの 5 例に噴切を施行しているが, 今回の検討対象からは除外した。

1）噴切の適応基準

当科での噴切の適応基準は, 術前のX線，内視鏡な どの諸検査から，および開腹時に得られる所見を総合 して, 以下のょうに規定している。

癌腫の占拠部位がC または CEで, 胃体部への進展 のみられない上部胃癌症例であること，このことは癌 腫からの肛門側断端距離を十分に確保した上で, 必要 なだけの幽門側胃の温存をはかるためである。

原則として，術前の壁深達度判定で $\mathrm{m}$ または $\mathrm{sm} の$ 表在癌と考えられる症例. 表在癌か否か判定に迷う症 例については，最悪でも，ごく軽微な $\mathrm{pm}$ 浸潤にとど まっているであろらと考学られると。

以上に加えて, 開腹時肝転移, 腹膜播種のないこと は当然として, 将膜漫潤を認めないSoで, しかも触診 などで pm 以上の漫潤はなく、リンパ節転移に関して も $\mathrm{n}($ (一) と考光られること.

すなわち, 当科では癌腫の肛門側への進展が Cにと どまる比較的小さな上部胃癌のうち, 組織学的に $\mathrm{m}$, $\mathrm{sm}$ の早期癌(もしくは，わずかな pm 浸潤にとどまる

表 5 噴切施行例の肉眼判定と組織学的検索結果の比較

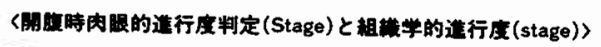

\begin{tabular}{|c|c|c|c|}
\hline Stage Stage & I & II & III \\
\hline${ }_{\mathrm{H}_{0} \mathrm{P}_{0} \mathrm{~S}_{\mathrm{O}} \mathrm{N}_{4}}$ & $\begin{array}{c}20 \\
3\end{array}$ & $\begin{array}{l}2 \\
4\end{array}$ & $\begin{array}{l}2 \\
1\end{array}$ \\
\hline $\begin{array}{l}\mathrm{H}_{0} \mathrm{P}_{0} \mathrm{~S}_{0} \mathrm{~N}_{2}: 1 \\
\mathrm{H}_{0} \mathrm{P}_{0} \mathrm{~S}_{2} \mathrm{~N}_{1}: 1 \\
1\end{array}$ & 1 & 0 & 1 \\
\hline $34 \mathrm{gm}$ & 24 & 6 & 4 \\
\hline
\end{tabular}

Stage I $\rightarrow$ stage I : 20/24 $83.3 \%$

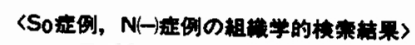

$S_{0}$ 症明 33 时

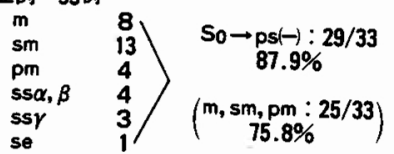

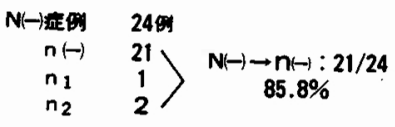


表 6 本邦諸施設における噴切の適応基準

\begin{tabular}{|c|c|c|c|c|c|c|c|}
\hline \multirow{2}{*}{ 施 設 名 } & \multirow{2}{*}{ 青著 } & \multicolumn{2}{|r|}{ 遒 } & \multicolumn{2}{|l|}{ 準 } & \multirow{2}{*}{ 俨 教 } & \multirow{2}{*}{ 文嗝 } \\
\hline & & リンパ简転移 & 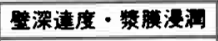 & 胆 & 肉 眼 型 & & \\
\hline m取大 - 1 外 & $\begin{array}{l}\text { 古贺ら } \\
\text { 貝原ら }\end{array}$ & & & $C, C E$ & $\begin{array}{l}\text { 早期船もしくはこれ } \\
\text { に䒨ずる限局性の溘 }\end{array}$ & $\begin{array}{l}\text { Cに限局性の早期独 } \\
\text { に対しては根治性に } \\
\text { 间首なし }\end{array}$ & $\begin{array}{l}\text { 7) } \\
\text { 12) }\end{array}$ \\
\hline \multirow[t]{2}{*}{ 九州大・2 外 } & 井ロら & 5，6に枟移(一) & & 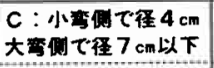 & 眼昌型 & & 17) \\
\hline & 井口ら & $\underset{\text { 転移(-) }}{4 \mathrm{~d}, 5,6 \text { に }}$ & 湜浬型ではS & 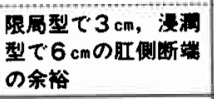 & 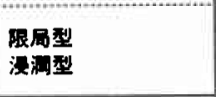 & 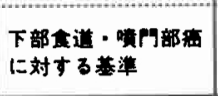 & 25) \\
\hline 賁北大 - 1 外 & 渡部的 & & & $\begin{array}{l}\text { C.CE } \\
\text { 徍 } 4 \mathrm{~cm} \text { 以下 }\end{array}$ & & & 26) \\
\hline 鹿肾息大・ 1 外 & $\begin{array}{l}\text { 西 ら } \\
\text { 要甲放 }\end{array}$ & 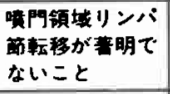 & $\begin{array}{l}\text { 早期司盘 } \\
\text { 限局型ではS 以下 }\end{array}$ & 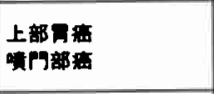 & $\begin{array}{l}\text { 限局型 } \\
\text { (早期田福) }\end{array}$ & & $\begin{array}{l}27) \\
28)\end{array}$ \\
\hline 群馬大・2外 & 宫本ら & $\begin{array}{l}5,6 \text { (事移(-) } \\
\text { (?) }\end{array}$ & $\mathbf{S}(-)$ & 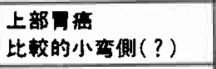 & $\begin{array}{l}\text { 限品型 } \\
\text { 中间型 }\end{array}$ & & 18) \\
\hline $\begin{array}{l}\text { 大肘医大・ } \\
\text { 一般消化器外科 }\end{array}$ & 風 息 & $\begin{array}{l}5,6,10,11 \\
\text { に転移(-) }\end{array}$ & $S_{1}$ 以下 & 唶門部荡 & & 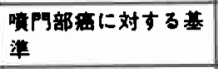 & 11) \\
\hline 熊本大. 2 外 & 三檑的 & & & 小さい粗門藏 & & 比效的早期の症例 & 9) \\
\hline 我研・外科 & 高木ら & 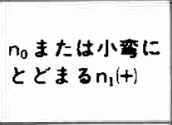 & 早期乘 & 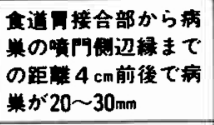 & & & 29) \\
\hline $\begin{array}{l}\text { 国立がんセンター・ } \\
\text { 外科 }\end{array}$ & れ山ら & $N(-)$ & $\begin{array}{l}\text { 早社密 } \\
\text { (m,sm) }\end{array}$ & $\begin{array}{l}C ： \text { 充分な断端の余 } \\
\text { 裕 }\end{array}$ & 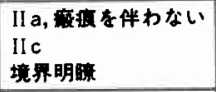 & & 8) \\
\hline 神戸大 - 1 外 & 大柳ら & & 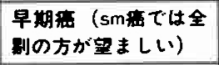 & c & & $\begin{array}{l}R_{2} \text { 䡉清を行なうこ } \\
\text { とが来件 }\end{array}$ & 10) \\
\hline 当 & 跲木ら & $\begin{array}{l}n(-) \\
N(-)\end{array}$ & $\begin{array}{l}m, s m(p m) \\
S_{0}\end{array}$ & $\mathrm{C}, \mathrm{CE}$ & 早期重 & $\begin{array}{l}\text { 咈切は編少手少術式 } \\
\text { と考えるへき }\end{array}$ & \\
\hline
\end{tabular}

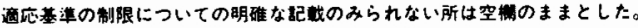

各相の佘現はできるたけ文献にあるとのままの形であらわした。

図 1 当科における噴門側胃切除術式

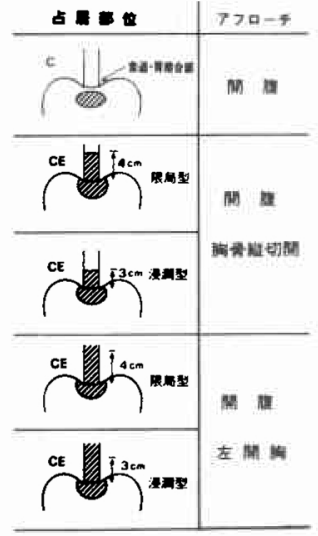

或の占是战位とアフローチ

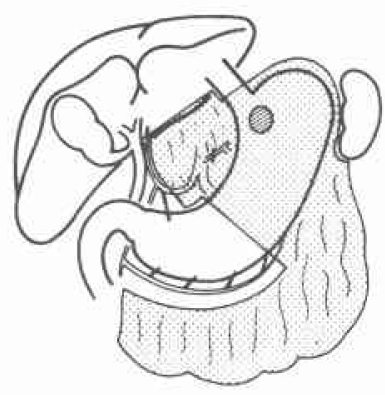

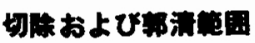
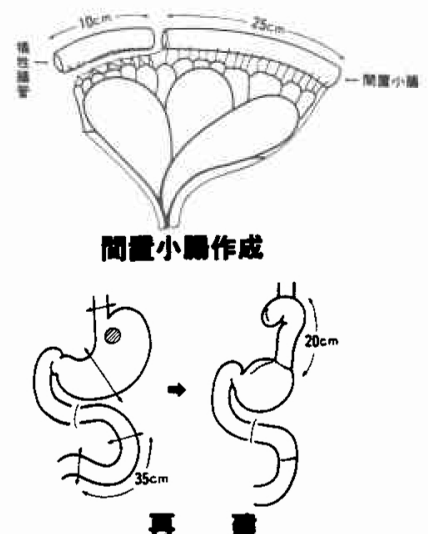

$\mathrm{pm}$ 癌) で, $\mathrm{n}(-)$ の stage I 胃癌と予測され, 開腹 時所見でも Stage I の早期癌と判断された症例を噴切 の適応例としている(表 6).

2）噴切の基本術式）（図 1 ）
当科に招ける噴切の基本術式について概略を述べ る.

i . 到達経路 (アプローチ)：局在 Cの症例は開腹 のみ, $\mathrm{CE}$ の症例は食道浸潤の距離, 癌腫の肉眼型によ 
り胸骨綐切開, もしくは左開胸を加え, 口側食道の十 分な切除と No. 110, No.111, No.112の郭清を可能に 寸る3(6).

ii. 切除：癌尰よりの断端距離は, 限局型で $3 \mathrm{~cm}$ 以 上, 浸潤型で $5 \mathrm{~cm}$ 以上とることを原則とし，食道およ び胃の切離線を決定する。残存幽門側胃は，小弯側で $5 \sim 10 \mathrm{~cm}$, 大弯側で $15 \mathrm{~cm}$ 程度とし, 全体として1/2 2/ 3の噴門側胃の切除となる，大網拉よび小網切除 $($ 網囊 切除）は, 右胃大網動・静脈, 右胃動・静脈を温存し つつ可及的に行 .

iii. リンパ節郭清: No. 1, No.2, No. 3, No. 4s は 胃壁につけたまま, No. 7, No. 8, No. 9は総肝動脈〜腹 腔動脈幹を露出し, 左胃動脈を根部で結禁, 切断し郭 清する.No.11は苹上縁に添い後胃動・静脈まで, 荤を 温存しつつ郭清する. 脾剔(No. 10郭清)は原則として 行わない. No. 4d, No. 5, No.6は右胃大網動・静脈, 右胃動・静脈を残胃の栄養血管として温存するため郭 清しない. 胸骨縦切開や左開胸を加えた場合にはNo. 110, No.111, No.112の郭清を行っておく3).

すなおち，当科での噴切は，上部胃癌においては転 移危険性の少ないとみられる No. 10, No. 4d, No. 5, No. 6を当初より郭清の対象から除いた， $R_{1}$ 郭清の根 治術式といえる。

iv. 再建：Treitz 勒帯より20３0cm の部から約35 $\mathrm{cm}$ の空腸を離断後, 結腸後, 順震動に挙上し, 食道 一残胃間に間置する. 食道・空腸は端側, 空腸・残胃 は端々に吻合する. この際, 挙上空腸の血行不全予防 のため, その肛門側約 $10 \mathrm{~cm}$ を犠牲腸管として切除し, 最終的な間置空腸の長さは約 $20 \mathrm{~cm}$ としている.

なお，幽門形成術は最近の症例では付加しないこと を原則としている。

2. 結果

1) 癌腫の局在と到達経路：対象例34例の局在は, $\mathrm{C} 31$ 例, $\mathrm{CE} 3$ 例で, 局在 Cのものは全例開腹のみ, $\mathrm{CE}$ の 3 例は開腹に胸骨綎切開を加穴切除を行っている.

2) 合併切除藏器：34例中28例と, ほとんどの症例で は他臓器合併切除を伴っておらず, 6 例のみに他臓器 合併切除が行われた. 合併切除藏器は, 脾 5 例, 䐙尾 部・脾 1 例であった。

3) 肉眼判定と組織学的検索結果の比較検討（表 5): 肉眼判定による Stageは, I 。 24例, II， 8 例 （全例 $\mathrm{H}_{0} \mathrm{P}_{0} \mathrm{~S}_{0} \mathrm{~N}_{1}(+)$ ), III. 2 例であった. Stage II, IIIの10例は昭和57年以前の症例で, 現在ではこのよう な应例は全剔を行い, 噴切の適応外としている. Stage
I 24例の組織学的進行度・Stage は, I . 20例, II, III それぞれ 2 例で, Stage I $\rightarrow$ Stage I と, 肉眼判定と組 織学的進行度が一致したものは83.3\%であった。

肉眼的に $\mathrm{S}_{0}$ と判定した 33 例の組織学的検索による 壁深達度は, ps（一）であったもの29例，87.9\%で， そのらち $\mathrm{m}, \mathrm{sm}, \mathrm{pm}$ 例が 25 例, $\mathrm{S}_{0}$ 症例全体の $75.8 \%$ 占めていた。 また, 術前の判定も含め, 肉眼的に表在 癌と診断したものは25例である.このうち 21 例, $84.0 \%$ が $\mathrm{m}, \mathrm{sm}$ 癌であり, 残り 4 例, $16.0 \%$ はs, $\mathrm{ps}(+)$ 例（それぞれ2例）であった。一方, 術中 $N(-)$ と 判断した例で, 組織学的にもn(一)であったものは, 24例中 21 例, $85.8 \%$ であった。

すなわち, 肉眼判定と組織学的検索結果は括おむね $85 \%$ 前後の症例で一致をみるが, 残りの $15 \%$ 前後では 肉眼判定の方が過少であったことが判明した。

4) リンパ節郭清度と根治度：リンパ節郭清度は, $\mathrm{R}_{1} 31$ 例， $\mathrm{R}_{2} 3$ 例であった。これら34例は肉眼的には治 瘾切除であったが，組織学的には 4 例が非治瘾切除上 なった. らち 3 例は $\mathrm{R}<\mathrm{n}$ の相対的非治㾤切除例で，す ベて $R_{1}$ 郭清例での No. 7転移陽性例, 残る 1 例は aw (十）例である.

5）予後：他病死 1 例を除く33例の術後累積生存率 を図 2 に示した。再発死亡例は 3 例及られているが, いずれす血行性転移（肝 2 例, 肺 1 例) がおすお死因. であった. 33例のうち, 早期癌症例が 20 例, $60.6 \%$, stage I 症例が23例， $69.7 \%$ と多くを占めていたが，全 体の累積 5 年生存率は $89.0 \%$ と良好な成績であった。

\section{III. 考 察}

上部胃癌に対する根治術式として, 噴切は全剔に比 較し，根治性で劣るものであるという認識は本邦各施 設に扣いて共通のものと考劣られる7 10). 一方, 噴切 がいろいろの施設で実施されているのは, 全剔より術 後の愁訴や生体機能の上で優れている面があると考兄

図 2 噴切施行例の術後累積生存率（Kaplan-Meier 法)

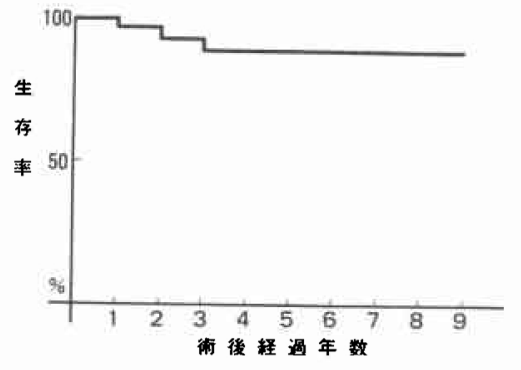


られ，特に術後長期に生存が期待される症例にはこの ことが重視されるからである111121. ゆ光に，それぞれ の施設ではこれらの点を考慮し, 噴切で根治性が満足 されると考兄られる比較的早期の上部胃癌症例を選択 し，本術式が行われているよらである．以下今回の検 索結果と, 本邦各施設からの発表とを対比しながら, 上部胃癌の臨床病理学的な特徵と, 適応基準など, 上 部胃癌に対する噴切施行上の問題点について考察を加 えた。

上部胃癌症例でリンパ節転移を認めたものは，C癌 について丸山ら ${ }^{8)} 56 \%$ 強, C, CM 癌について垬ら ${ }^{13)}$ は72.2\%であったと報告し，当科での $83.1 \%$ という值 之同様，高率であるが，噴切の適応を考学る場合，特 飞 No. 4d, No. 5, No.6転移の有無は, 術式から考克 てこれらリンパ節の郭清が困難なため重要である。こ

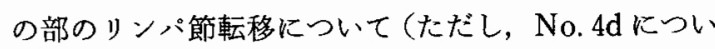
ては, 胃癌取扱い規約・改訂第 9 版年以前は大弯リンパ 節, No. 4）は全剔例を対象として, 癌腫の壁深達度, 局在，肉眼型などと関連して多くの検討がなされてい る.

西ら ${ }^{14)}$ は噴門部癌 ${ }^{15)}$ 除く上部胃癌症例で, No. 4 19\%, No. 5 3\%, No. 6 9\%の転移率であったと報告 し, 堺ら ${ }^{13)}$ は C, CM 癌でこれらリンパ節の転移率は,

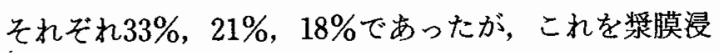
潤の有無で検討した場合， $\mathrm{s}_{0}$ で $5 \%, 0 \%, 0 \%, \mathrm{~s}(+)$ で43\%，26\%，23\%と著しい差を認めたとい5．貝原 ら ${ }^{12)}$ は C, $\mathrm{CE}$ 癌ではこれらリンパ節への転移は 1 〜 $2 \%$ 以下であるのに対し，浸潤が胃体部まで及んだ $\mathrm{CM}, \mathrm{CME}$ 癌ではNo.4d 18\%, No.6 6\%と転移率 の上昇を認め, 同じ施設の古賀ら”は, 局在 Cで ss で, CM では pm でのものは No. 4d, No. 5, No.6 に転移をみなかったと，さらに詳しく検討を行ってい る. また佐々木ら ${ }^{16)}$ 。局在 C 癌では壁深達度にかか わらず，No. 5, No. 6亿転移（一）であったが，CM 例では se, si 症例に $22.2 \%$ と同率の転移がみられたと

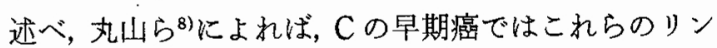
パ節に転移を認めなかったという。一方, 癌腫の肉眼 型を含めた検討で, 井口ら ${ }^{17)}$ は局在 Cの限局型ではこ れらリンパ節に転移をみなかったのに対し，浸潤型で は No. 5 8.7\%, No.6 25.0\%の転移率であったとし, 宮本ら ${ }^{18)}$ は小弯の上部胃癌で, 限局型または中間型の S (一) 例ではNo. 5, No.6への転移は泀とんどみら れないと述べている。

当科ではこれら 3 領域のリンパ節を一括して検討し
たためか，その転移率は $26.9 \%$ ，他施設に比較して やや高率であった。 しかし, No. 4d, No. 5, No.6へ の転移は，壁深達度の進展した ps（十）例で高頻度に なるといらことが共通した結果と考光られ，ps（一） 例については, pm以下, そのなかでも特に早期癌は転 移の危険性が少ないといえるよらである。

癌腫の局在では, 胃体部へ癌巣が拡がると, これら リンパ節への転移が増加するとい党そらである。この 結果は，Mに浸潤が及ぶ上部胃癌は，Cにとどまるも のに比べて進行例が多くなるすのと予想されること, これらのリンパ節へも近く、リンパ流の関俰 ${ }^{19)}$ からみ て転移をきたしやすくなることなど，いくつかの要因 が影響しているためと考兄られる。

上部胃癌に抢いては脾門 (No. 10), 脾動脈幹 (No. 11）リンパ節への転移についての検討も重要である.

西ら ${ }^{14)}$ は先に述べた上部胃癌症例を対象とし, No. 10，No.11にそれぞれ $26 \%$ ，25\%の転移率をみており， さらに局在が後壁や大弯の時は，一次リンパ節と考兄 るべきものとして, 転移の危険性と郭清の必要性を強 調している20).武藤ら ${ }^{211}$ は C 癌で, No. $1026.3 \%$, No. $1124.7 \%$,西らとほ湆同様の転移率であったことを 述べるとともに, 癌腫の壁梁達度との関係からも検討 を加克， $\mathrm{s}($ 一)例のこれらリンパ節転移率 $4.9 \%, 12.2 \%$ に比較して, $\mathrm{s}(+)$ 例では $31.8 \%, 28.0 \%$ と, s (+) 例で著しく高い転移率となることを発表している。癌 腫の局在をる加味した検討で, 岸本ら 221はこれらリン パ節への転移は，M をたは全胃に及んだ $\mathrm{ps}(+)$ 例で 多く, No.10には $23.0 \%$, No.11には27.9\%の症例に 転移陽性であるのに対し, ps（一）例ではそれぞれ 5.4\%，0\%の転移率であったといい，佐々木ら ${ }^{16)}$ 壁 深達度の進展とともに, 胃体部へ浸潤が搪がると, No. 10, No. 11への転移が増加することを述べている。

すなおち, これら各施設の発表から, No. 10, No. 11 についても, 当科での検索結果と同様, 壁深達度から みて進展した例や，胃体部に病巣の拡がりを有するも ので転移率が上昇することが判明している。

上部胃癌に打ける所属りンパ節転移の相関につい て, 武藤ら ${ }^{21}$ は C 癌症例で, No. 10, No. 11の転移率 と No. 1,3 ; No. 2,4 ; No. 5, 7, 8, 9 ; No. 4d,6のリン パ節群における転移の有無との関係から詳細に検討 し, これらリンパ節群に転移(+)の時にNo. 10, No. 11への転移が増加することを述べ，特に 1 群リンパ節 転移陽性例では No. 10, No. 11転移率が $40 \%$ 前後と高 率となることを強調している。 また中島ら ${ }^{23)}$ も連関測 
度 $\gamma$ を指標として胃癌の所属リンパ節の転移パター ンを解析した結果, 上部胃癌に招いてはNo. 10, No. 11 とo. 2, No. 3 リンパ節との間の連関の高いことを 明らかにした。

一方，いろいろの物質を生体に注入し，直接的に胃 のリンパ流を知る試みもなされている，丸山ら 24)はリ ピオドールやパテントブルーを用いた噴門・胃体上部 のリンパ流の検索により,小弯側から腹腔動脈幹周囲, 大弯側や胃後壁から脾門, 脾動脈へと流れる経路を証 明し，各部位のリンパ節の関連性について一つの示唆 を与党ている.才原 ${ }^{19}$ は ${ }^{99 m} \mathrm{Tc}$-Rhenium colloidを用 いて胃リンパ系の臨床的研究を行ない, 噴門部での小, 大弯側リンパ節と腹腔動脈幹周囲，脾門リンパ節との 関連性を臨床例と対比しながら明らかにしている。 た，胃中部では，小弯側から腹腔動脈幹周团，幽門上 へ，大弯側から幽門下，脾門，脾動脈幹へのリンパ流 を認めているが, このことは癌腫が胃体部へ進展した 症例で No. 4d, No. 5, No.6への転移が増加するとい 5, 諸施設からの発表と関連するものと思われる。

以上の結果は, 当科での成績も含め, いずれも上部 胃癌進展に拈ける各所属りンパ節間の密接な関連性を 裏付けるものである. 具体的には，小弯側や大弯側の 1 群リンパ節に転移 $(+)$ の場合には，それぞれに関 連の深い 2 群リンパ節への転移の危険性が高くなると いらことと同時に， 1 群リンパ節転移の有無が 2 群リ ンパ節転移を予測する上で重要な意味をすつといらこ とが言えるであろう。

われわれは上部胃癌における所属リンパ節の転移危 険性といら概念を想定した上で，これらリンパ節への 転移のしやすさは, 1 群リンパ節 $>$ No. 7, 8, 9 $11 \geqq N o .4 \mathrm{~d}, 5,6>$ No. 10の順になるであろ5と推測し た.このことから当科では上部胃癌でも 1 群リンパ節 転移陽性例や，No. 7,8,9転移陽性例，ps（十）例な どの進行した症例では, 胃体部や幽門部の癌と同じく No. 4d, No. 5, No.6は転移をさたす可能性の高い》 ンパ節であり，No. 10, No. 11とともにその郭清が重 要であると考劣ている.文献上で確認しらる限りでは, 検索対象や検討の内容，方法などが同一でないためか， これらリンパ節の転移率が施設により異なって掞り， 一概にはいえないものの，これまで上部胃癌に対する 根治手術に際しての No. 4d, No. 5, No.6郭清につい て，他の 2 群リンパ節との比較において，その重要性 を強調したすのは少ないようである、今後の諸施設に おける御検討，御批判を期したいところである。
上部胃癌に対する噴切の適応については，これまで 述べた臨床病理学的検索や，特に全剔施行例との予後 の比較などから，各施設ごとにいろいろの基準が設定 されている. 表 6 に本邦墸施設での噴切適応基準を, それぞれの発表を参考にしてまとめてみた。

癌腫の局在, 拡がりについて，的れわはおもに肛 門側断端距離の確保之幽門側胃の温存とのかねあいか ら, 肛門側への進展範囲が C 領域にとどまることが噴 切適応の一条件になることを述べた。この点について は他施設でもほぼ同様の考え方のようであり，断端距 離の問題のほかに，胃体部に浸潤が及ぶ場合にはNo. 4d, No. 5, No.6への転移が高率になることも考慮し, 上部胃癌で $M$ 領域に進展をみる症例は本術式の適応 外としているようである。

しかし癌腫の進行度については，噴切の根治性を考 慮し, 全剔に比較して早期の症例に本術式を適応とす ることを原則とする施設が多いようであるが，各施設 ごとに多少の相違点がみられている。

現在当科では, 術前, 術中の総合判定で Stage Iの 表在癌と判断され, 組織学的にも stage I $の \mathrm{~m}, \operatorname{sm}(8)$ しくはわずかな pm 浸潤のみを認める pm) 癌と予想 される症例のみを噴切の適応としている。昭和56 57 年まではわれわれの施設においても，pm以上の壁深 達度と考えられても $\mathrm{S}_{0}$ と判断された症例や， $\mathrm{N}_{1}(+)$ 例，さらにはNo. 7, 8, 9中 No. 10, No.11に転移が疑 われた症例に対して, No. 4d, 5,6に転移のないことを 術中迅速標本にて確認した上で，膵や脾の合併切除を 伴った噴切を施行した症例が少数ながらみられてい、 る2). しかし, それ以降, このよらな症例は噴切の適応 外とした。このことは上部胃㿋根治手術として噴切は, 術後生体機能の障害を最小限にとどめることを目的と して, 胃切除範囲, リンパ節郭清範囲を必要かつ十分 な程度に控えた，一つの縮少手術術式とするというこ とを当科の基本的な考方方とし，同時に，幽門側胃を 温存した上で, リンパ節郭清の面からも脾門部 (No. 10)，大弯右 (No. 4d), 幽門上・下 (No. 5,6) のリ ンパ節を郭清の対象から除いた， $\mathrm{R}_{1}$ 郭清で十分な根治 性が得られると判断される早期の症例のみに本術式を 適応とすることを原則としたためである。一方，浆膜 浸潤陽性例や， 1 群，2 群を問わずリンパ節転移陽性 と考觉られた症例に対しては，各所属リンパ節間の転 移における関連性や，No. 4d, 5, 6リンパ節の No. 10 やNo. 11と比較した場合の転移危険性の高さなどを 考光, 噴切よりも, より根治珄の高い，腪や脾の合併 
切除と $\mathrm{R}_{2}$ 以上の郭清を伴う全剔を施行することとし た。 1 群リンパ節転移陽性と考えられる症例, さらに は明らかな $\mathrm{pm}$ 癌と考光られる症例をる噴切の適応外 としたが, このことは先の臨床病理学的検索結果とと 6に, 肉眼的進行度判定が組織学的検索結果に比較し て15\%前後の症例で過少であったという，当科噴切施 行例での検討結果から，No. 4d, 5,6やNo. 10に転移 を認める危険性の高い進行例に噴切を行うことを避け るため, 術前, 術中の壁深達度やリンパ節転移につい ての判定に対しては適切な安全域を確保する必要があ ると考えたためである。

丸山ら 8 は過去に打ける喷切施行例の検討で，その 5 生率は $37.0 \%$, 全剔例の $55.4 \%$ より有意に低く, stage 別にみても有意に噴切例の予後が不良であった と述べ，さらに再発形式についても，噴切例に腹膜再 発が多く, 明らかに全剔より根治性で劣り, ごく限ら れた症例のみしか噴切を行らべきでないとして，その 適応基準を厳しくしており，当科とほぼ同様の考方方 を示している.

しかし, 膵や脾など, 他蔵器の合併切除を加兄, あ る程度進行した症例にる積極的に噴切を施行している 施設からの発表として, 鳥取大・1 外 ${ }^{712222)}$ では, C, $\mathrm{CE}$ 癌には噴切を行うことを原則として拈り，その治 瘜切除例の 5 生率は全剔例の $61 \%$ に対して $58 \%$ ，また stage III 症例に限ってみても，それぞれ35\%,33\%で, いずれも差を認めて扣らず, 井口ら ${ }^{17)} \mathrm{C}, \mathrm{CE}$ 癌に対 する噴切施行例のうち，治瘾切除例の 5 生率は $52.0 \%$ で, C, CM, CE 癌に対する全剔, 治瘜切除例の $41.2 \%$ に比較して良い值であり，適応を選べば噴切の予後は 以外と良好であったと述べている。

当科での噴切施行例の累積 5 年生存率は $89.0 \%$ と, 早期癌を含む stage I 症例が69.7\%と多くを占めてい たことを考慮にいれても，ほ注満足できる良好な成績 であったが，これらの成績の差は，各施設に和ける噴 切の適応対象の進行度の違いが大きな要因と考えられ る.

施設による癌腫の進行度についての噴切適応基準の 相違は，噴切の全剔に比較した場合の根治性に拈ける “Inferiority”をどの程度に考えるかといらことに基づ くものと思われ，このことがリンパ節郭清範囲，他臓 器の合併切除を加えるか否かなど，術式自体の違いに る表われているよらである。当科では，前述のごとく， 噴切は一つの縮少術式であり，限られた早期の症例の みが適応になるといら考方方を基本として招り，他方
No.10やNo.11に転移が認められるなど，膵や脾の合 併切除を必要とするような症例は, No. 4d, No. 5, No. 6転移の危険性も考兄て，また浆膜浸潤 (十)の場合に は，これらリンパ節への転移の危険性が高くなること に加充, 前述の丸山らの報告のごとく術後の腹膜再発 の問題む含め, より根治性の高い術式一全剔が望まし いと考えている.

いずれにしても，現時点では各施設における上部胃 癌に対する噴切施行の問題についてはいろいろの考党 方があり，一致をみない点もいくつか残されているよ らである．今後これらの点について，さらに検討を要 するるのと考兄られる。

\section{IV. 結 語}

1. 上部胃癌に対し全剔を施行した124例の臨床病理 学的検索から,これら症例のリンパ節転移が高率なこ と, 各所属リソパ節間の転移に扣ける関連性の強いこ と, 癌腫の壁深達度が進む程, リンパ節転移率む上昇 することが明らかになった。加えて転移危険性という 概念を想定した場合, No. 4d, 5, 6の転移危険性はNo. 10 , No.11 同等以上であり, 上部胃癌症例に招いて あ, 特に $\mathrm{n}_{1}(+)$ p $\mathrm{ps}(+)$ 例など, 進行した症例で は胃体部や幽門部の癌と同しく，郭清の必要性の高い リンパ節群であると考えられた。

2.われわれの噴切に対する基本的な考方方は，上部 胃癌に対する根治手術としては, 術後の生体機能をで きるだけ温存するため，胃切除範囲，リンパ節郭清範 囲を必要かつ十分な程度にとどめた，一つの縮少手術 術式といらことにある。

3.このような考方方から, 当科での噴切は $1 / 3 \sim 1 /$ 2 の幽門側胃を温存し, No. 10, No. 4d, No. 5, No. 6を郭清の対象から除いた $\mathrm{R}_{1}$ 郭清で，原則として荤や 脾など, 他葴器の合併切除を伴わない術式を基本術式 としている.

4. 根治性が満足され, しかも適切な安全域を確保し た上で噴切を施行できる症例は, 局在 C (E) の比較的 小さな $\mathrm{N}(-)$ の表在癌で, 組織学的にも $\mathrm{m}, \mathrm{sm},(\mathrm{pm})$, $\mathrm{n}$ (一) と考えられる早期の上部胃癌症例であり, それ 以外の症例では No. 10 No. 4 d, No. 5 , No. 6を含 を $\mathrm{R}_{2}$ 以上の郭清を伴う全剔が望ましい。

\section{文献}

1）鈴木 力, 栗根康行, 北村正次注か：術后生体機能 からみた上部胃癌に対する噴門側胃切除術と胃全 剔術の比較。日消外会誌 $17: 1166,1984$

2）片柳照雄, 栗根康行, 北村正次汪か：上部贯癌に対 
する噴門側切除，空腸間置術とくに術式と適応に ついて. 手術 35:123-127, 1981

3）栗根康行, 北村正次, 小西敏郎注か：下部食道噴門 癌に招ける下部胸腔内リンパ郭清。手術 38 ： 1047-1052, 1984

4）胃癌研究会編：胃癌取扱い規約。改訂第 9 版, 東 京, 金原出版, 1974

5）胃癌研究会編：胃癌取报い規䄪．政訂第10版，東 京, 金原出版, 1979

6）栗根康行：胸骨鋌切開，綎隔経路に上る食道噴門 癌根治手術と手術成嘖. 現代外科学大系, 年間追補 1979-C. 東京, 中山書店, 1979. p59-70

7）古賀成昌，西村興严：噴門部早期胃癌に対する手 術術式の選択；術後の一般状態とホルモン動態か 5. 消外 6:1435-1442, 1983

8）丸山圭一, 北岡久三, 平田克治注か：噴門部癌に対 する手術術式の選択；根治性から．消外 6： 1425-1431，1983

9）三隅厚信, 赤木正信, 馬場憲一郎注か：噴門癌の外 科的治療飞打ける問題点一近側胃切除術と胃全剔 術の比較一. 日消外会誌 $17: 6-14,1984$

10）大柳治正, 多淵芳樹, 斉藤洋一：胃全摘後の再建術 式とその問題点. 外科治療 $50: 450-458,1984$

11）岡島邦雄：手術術式の選択一再建法をどうするか 一. 臨外 $34: 1838-1844,1979$

12）貝原信明, 西村興垔, 古賀成昌：癌噴門切除か全摘 か. 癌の臨 $30: 1052-1056,1984$

13）堺 哲郎, 藤巻雅夫, 金井 弘渒か：上部胃癌に対 する切除術一胃壁癌哚達度とりンバ節転移の実態 に関連して一. 手術 $23: 129-137,1969$

14）西 満正, 加治佐隆: 下部食道噴門癌の外科的治 療. 現代外科学大采, 年間追補1977-C. 東京, 中 山畫店, 1977, p3-55

15）西 满正, 加治佐隆, 阿久根務汪か：噴門部癌につ いて一食道胃境界部癌の提唱一, 外科猃療 15 ： 1328-1338, 1973

16）佐々木廸郎, 市川健寛, 菅優洼か：胃上部(噴 門部)癌のリンパ節転移一幽門上下, 脾門リンパ節
転移について一. 臨外 $31: 377-380,1976$

17）井口潔, 脇田政康, 副島一彦名：適応の吟味 一適正な適応一。臨外 $29: 311-318,1974$

18）宮本幸男, 泉雄 勝, 東郷庸史注か：噴門側胃切除 術に打ける器械吻合. 食道胃管端側吻合. 手術 $38: 799-806,1984$

19）才原哲史：Radio Isotope Lymphographyによる 胃リンパ系の臨床的研究一をくに, 胃癌のリンパ 節転移との比較一. 医研究 $54: 447-471,1984$.

20）西 満正, 中島聡総, 関 正威流 : 近側胃切除術 に打ける術式の検討. 外科治療 $23: 290-306$, 1970

21）武藤輝一, 川口正樹, 田中乙雄活か：胃全摘におけ る脾摘一合併脾摘の適応。手術 $36: 331-336$, 1982

22）岸本宏之, 田中公晴, 前田廸郎ほか：胃全摘および 噴門側胃切除における脾または愺脾合併切除の検 討。日消外会誌 $12 ： 971-975,1979$

23）中島聡総, 高橋知之, 吉田行一ほ を指標とした胃癌のリンパ節転移パターンと郭清 法の検討。臨外 39：1589-1597, 1984

24）丸山圭一, 三輪 潔, 河村 譲ほか：噴門部のリン 八流と癌の転移一Lymphography による検討。胃 之腸 $13: 1535-1542,1978$

25）井口 潔, 杉町圭蔵, 神代龍之助ほか：下部食道・ 噴門部癌手術術式の選択・1一特に口側・肛門側切 除範囲の検討. 消外 $5: 1861-1866,1982$

26）渡部忠信, 佐久間晃：上部胃癌の壁内進展战よび リンパ節転移よりみた手術術式選択阙する臨床 病理学的研究。 日外会誌 $78: 395-407,1977$

27）西 满正, 野村秀洋: 胃癌の手術術式と予後。消外 $2: 327-334,1979$

28）愛甲 孝, 西 满正, 加治佐隆ほか：食道胃境界領 域胃癌の再建術式。手術 32:873-880, 1978

29）高木国夫, 太田博俊, 野口芳一：早期胃癌の手術. 域所 他監修, 胃癌の臨床, 東京, 一るす出版, 1983, p426-444 